\title{
RELATIONSHIP BETWEEN DIFFERENT AMOUNTS OF BROOD AND THE COLLECTION AND USE OF POLLEN BY THE HONEY BEE (APIS MELLIFERA)
}

\author{
Richard L. HELLMICH, II (1) and Walter C. ROTHENBUHLER \\ Entomology Department, The Ohio State University, Columbus, OH 43210, U.S.A.
}

\section{SUMMARY}

Observation colonies each with approximately 1000 bees were given three levels of brood $(0,100$ and 400 cells). Foraging was restricted to artificial sources in flight cages. Collection, storage and use of pollen increased with brood level. Eggs and larvae stimulated pollen foraging, and Iarvae, particularly older larvae, stimulated pollen use.

\section{INTRODUCTION}

The relationships of pollen and honey to brood rearing are often oversimplified by the beekeeper. For instance, an old beekeepers' aphorism states « a colony needs one cell of honey and one cell of pollen to rear a young bee ». This certainly is an easy formula to remember, but it suggests nothing about the complex behaviors of the honey bee which result in brood care and nectar and pollen collection. This investigation is concerned with the role of pollen in colony organization and in particular pollen collection, pollen use and brood care, and the relationships of these factors when brood amounts are varied.

Filmer (1932) noted overwintered colonies had more pollen collectors than colonies established from packages, because they generally had larger amounts of brood. Louveaux (1950) reported that a swarm collected little pollen until he added three frames of brood; and FuKUDA (1960) noted that pollen collection by a swarm was low until larvae were present. FreE (1967) determined that foraging in general and pollen foraging in particular was related to the amount of brood that was given to a colony. TODD and REED (1970) showed that amount of pollen

(1) Present address : Honey Bee Breeding, Genetics and Physiology Research, A.R.S., U.S.D.A., 1157 Ben Hur Rd., Baton Rouge, LA 70820, U.S.A. 
collected was closely correlated with amount of brood but reached an upward limit at approximately 800 square inches $\left(\sim 5200 \mathrm{~cm}^{2}\right)$ of brood (sealed and unsealed). JAYCOX (1970) showed that when nectar was not available, larvae influenced pollen collection more than either a queen or extracts of larvae. Larval extracts also were shown to increase nectar and pollen foraging.

In the following investigation, three levels of brood $(0,100$ and 400 cells) were used to determine how different amounts of brood influence pollen collection, pollen storage and pollen use. Measured amounts of brood with known numbers of adult bees whose foraging is restricted by flight cages are expected to confer the maximum experimental control of colony variables.

\section{MATERIALS AND METHODS}

Three one-frame observation hives were paced in a hive-shelter which had attached flight cages (Rothenbuhler et al., 1968). Approximately 1000 workers $(0-24 \mathrm{hrs}$ old) from a single source were placed in each of the hives. Bees were given sugar syrup (2.9 molar) in glass-jar gravity feeders only the first two or three days after the bees were installed. Recently collected pollen was provided to the colonies each day until the bees were old enough to forage. This pollen and the stored sugar syrup allowed normal development of worker brood-food glands. Water was available in glass-jar gravity feeders throughout the experiment. Temperature inside the shelters was maintained at $32^{\circ} \mathrm{C} \pm 1$ " $\mathrm{C}$ and a fan was used to circulate air.

When bees were 10 to 12 days old each colony was trained (WENNER, 1961) to sugar syrup (2.9 molar) in a petri dish which was located on a table three meters from the hive entrance. After the bees were trained to forage for sugar syrup in a petri dish they readily switched to pollen foraging when the syrup was removed and a petri dish of pollen was presented. The pollen was collected from pollen traps, dried and ground with a Wiley mill that had a $1 \mathrm{~mm}$ diameter sieve.

Three brood levels were used : 0,100 and 400. Eggs were obtained by placing queens from randomly selected colonies under excluder cages. The following morning the combs were removed and 100 or 400 eggs were counted per comb. Additional eggs were destroyed.

Three trials were conducted starting May 20, June 13 and July 5. Each trial lasted twelve days and included hatching of eggs, capping of brood and a two-day period following brood capping.

Each morning of the experiment between 9:00 and 10:00 o'clock, $20 \mathrm{ml}$ of sugar syrup was set on a table inside the flight cage for each colony. Two hours later two petri dishes containing a total of $20 \mathrm{~g}$ of ground pollen were put into a $12 \times 28 \times 13 \mathrm{~cm}$ plastic container. This container caught most of the pollen scattered by the bees while foraging. By the time the pollen was placed on the table the sugar syrup was depleted so only pollen-foraging activities were observed. Pollen was accessible to foragers for five hours.

Collection of pollen was measured daily by two different methods : 1) Pollen Weight - Amount of pollen removed during five-hour foraging period, 2) Pollen Foragers - Number of pollen foragers counted in three five-minute periods. Stored pollen was measured each day by counting the number of cells with pollen after the five-hour foraging period at 5:00 o'clock. Relative amount of pollen used by each colony during a 16-hour period was indicated by subtracting the number of cells containing pollen at 9:00 o'clock in the morning from the number of cells containing pollen at the end of the pollen-foraging period the previous day. 
One-way ANOVA was used to analyze each day of the pollen-storage data and all days pooled for pollen-weight and pollen-use data; brood treatment was the grouping factor. Two-way ANOVA was used to analyze pollen-weight, pollen-forager and pollen-use data where brood treatment and brood stage were the grouping factors; and days within brood stages were pooled. Walker-Duncan k-ratio t-test was used to separate treatment and brood-stage means.

\section{A. Pollen Storage}

\section{RESULTS AND ANALYSES}

Colonies that were given 400 cells of brood had stored larger amounts of pollen than the colonies that were given 100 or 0 cells of brood (Tabl. 1). These differences were significant every day of the experiment except the last day of the larval stage (day 9) and the first day capped brood was present (day 10). Pollen storage each day of the experiment was not significantly different between colonies that were given 0 or 100 cells of brood.

TABL.1. - Mean number of cells with pollen counted each day for each brood treatment

\begin{tabular}{|c|c|c|c|c|c|}
\hline \multirow{2}{*}{ Day of experiment } & \multicolumn{5}{|c|}{ Cells of brood } \\
\hline & 400 & 100 & 0 & $P>F$ & \\
\hline 1 & 71 & 39 & 37 & 0.01 & A B C \\
\hline 2 & 124 & 53 & 55 & 0.01 & $\mathrm{~A}$ C B \\
\hline 3 & 159 & 63 & 62 & 0.02 & A B C \\
\hline 4 & 183 & 69 & 57 & 0.02 & $\overline{\mathrm{A}} \overline{\mathrm{BC}}$ \\
\hline 5 & 188 & 76 & 55 & 0.02 & $\overline{\mathrm{A}} \overline{\mathrm{BC}}$ \\
\hline 6 & 199 & 75 & 60 & 0.04 & $\mathrm{~A} \overline{\mathrm{BC}}$ \\
\hline 7 & 204 & 79 & 71 & 0.02 & $\bar{A} \overline{B C}$ \\
\hline 8 & 187 & 77 & 74 & 0.05 & A B C \\
\hline 9 & 169 & 80 & 81 & 0.07 & \\
\hline 10 & 155 & 79 & 92 & 0.11 & \\
\hline 11 & 161 & 81 & 100 & 0.05 & $\overline{\mathrm{A}} \overline{\mathrm{C}} \mathrm{B}$ \\
\hline
\end{tabular}

Treatments are designated as : A (400), B (100) and C (0) cells of brood. Treatment letters connected by a line are not different as indicated by the Waller-Duncan k-ratio t-test.

\section{B. Pollen Collection}

Two trends were apparent : 1) pollen collection increased as brood levels increased; and 2) pollen collection by colonies that were given brood decreased 
from the beginning of the experiment to the end of the experiment (Tabls. 2 and 3). Results of the pollen-weight measures and the pollen-forager counts were similar; therefore, only the results of the pollen-weight measures were analyzed in detail.

TABL. 2. - Mean daily weights of pollen $(\mathrm{g})$ removed from feeders per five-four foraging period for each treatment and during four brood stages

\begin{tabular}{|c|c|c|c|c|c|c|}
\hline Cells of brood & $\mathbf{E}$ & $L_{1}$ & $\mathrm{~L}_{2}$ & PC & $P>F$ & \\
\hline 400 & 5.5 & 4.7 & 3.4 & 2.6 & $(0.04)$ & $\overline{\mathrm{E} \mathrm{\textrm {L } _ { 1 }}} \overline{\mathrm{L}_{2} \mathrm{PC}}$ \\
\hline 100 & 3.2 & 2.4 & 1.8 & 1.3 & $(0.04)$ & $\overline{\mathrm{E} \mathrm{L_{1 }} \mathrm{L}_{2} \mathrm{PC}}$ \\
\hline 0 & 2.8 & 0.8 & 1.6 & 2.0 & $(0.06)$ & \\
\hline$P>F$ & $\begin{array}{c}(0.05) \\
\text { A B C C }\end{array}$ & $\frac{(0.01)}{\bar{A} \overline{B C}}$ & $(0.09)$ & $(0.13)$ & & \\
\hline
\end{tabular}

Treatments are designated as : A (400), B (100) and C (0) cells of brood. Brood periods are designated as : $\mathbf{E}$ (egg stage), $\mathrm{L}_{1}$ (first-half larval stage), $\mathbf{L}_{2}$ (second-half larval stage) and $P C$ (post-capping stage). Treatment and brood-stage letters connected by a line are not different as indicated by the Waller-Duncan k-ratio t-test.

TABL. 3. - Mean number of pollen foragers per 15-minute observation period for each treatment and during four brood stages

\begin{tabular}{|c|c|c|c|c|c|c|}
\hline Cells of brood & $\mathrm{E}$ & $\mathrm{L}_{\mathrm{L}}$ & $\mathrm{L}_{2}$ & $\mathrm{PC}$ & $P>F$ & \\
\hline 400 & 27.3 & 20.8 & 17.2 & 9.3 & $(0.02)$ & $\overline{E L_{1}} \mathrm{~L}_{2} \mathrm{PC}$ \\
\hline 100 & 17.0 & 12.6 & 10.6 & 5.7 & $(0.003)$ & $\mathrm{E} \mathbf{L}_{1} \mathbf{L}_{2} \overline{\mathbf{P C}}$ \\
\hline 0 & 14.9 & 4.0 & 10.4 & 11.7 & $(0.26)$ & \\
\hline $\mathbf{P}>\mathbf{F}$ & $(0.06)$ & $\begin{array}{c}(0.03) \\
\mathrm{A}-\overline{\mathrm{BC}}\end{array}$ & $(0.32)$ & $(0.18)$ & & \\
\hline
\end{tabular}

Treatments and brood stages are designated as in Table 2. Treatment and brood-stage letters connected by a line are not different as indicated by the Waller-Duncan k-ratio t-test.

Total weights of pollen collected by the colonies were different from each other $(p<0.01)$. Treatment means indicate 400 -cell colonies collected the most pollen $(46.0 \mathrm{~g}), 100$-cell colonies collected intermediate amounts $(24.7 \mathrm{~g})$ and 0 -cell colonies collected the least amounts of pollen $(19.3 \mathrm{~g}$; Waller-Duncan 
test was used to separate means). More information was obtained when subsets of these means were analyzed. During the egg stage (days 1-3) and first-half larval stage (days 4-6) colonies that were given 400 cells of brood collected more pollen than colonies that were given 100 or 0 cells of brood (Tabl. 2). Similar differences were found during the second-half larval stage (days 7-9) and two days when capped brood were present (days 10-11), but differences during these two periods were not significant.

Colonies that were given brood collected the largest amounts of pollen during the egg stage; and decreasing amounts of pollen were collected through the remaining periods analyzed (Tabl. 2). Colonies with no brood also collected more pollen during the first three days of the experiment than any other period; however, these differences were not significant. Pollen collection by colonies with 0 or 100 cells of brood was not significantly different for any of the four periods analyzed.

\section{Pollen Use}

The total amounts of pollen used by the colonies were different from each other $(\mathrm{p}<0.002)$. Treatment means indicate 400 -cell colonies used the most pollen (165 cells), 100-cell colonies used intermediate amounts (70 cells) and 0 -cell colonies used the least amounts of pollen (43 cells; Waller-Duncan test was used to separate means). More information again was obtained when subsets of means were analyzed. During the first half (days 4-6) and second half of the larval stage (days 7-9) colonies that were given 400 cells of brood used significantly more pollen than colonies that were given 100 or 0 cells of brood (Tabl. 4). There were no significant differences in pollen use by colonies during. the egg stage (days 1-3) or the post-capping period (days 10-11).

TABL. 4. - Mean daily number of cells with pollen emptied by bees dwing a 16-hour period for each treatment and during four brood stages

\begin{tabular}{|c|c|c|c|c|c|c|}
\hline Cells of brood & $\mathrm{E}$ & $\mathrm{L}_{\mathrm{t}}$ & $\mathbf{L}_{\mathfrak{z}}$ & PC & $P>F$ & \\
\hline 400 & 8 & 19 & 22 & 9 & $(0.008)$ & $\overline{L_{2} I_{1}} \overline{P C E}$ \\
\hline 100 & 7 & 7 & 7 & 3 & $(0.11)$ & \\
\hline 0 & 6 & 3 & 3 & 4 & $(0.49)$ & \\
\hline$P>F$ & $(0.92)$ & $\begin{array}{l}(0.008) \\
\overline{\mathrm{A}} \overline{\mathrm{BC}}\end{array}$ & $\begin{array}{l}(0.001) \\
\text { A } \overline{\mathrm{BC}}\end{array}$ & $(0.22)$ & & \\
\hline
\end{tabular}

Treatments and brood stages are designated as in Table 2. Treatment and brood-stage letters connected by a line are not different as indicated by the Waller-Duncan k-ratio t-test. 
Colonies that were given 400 cells of brood used significantly more pollen during the first and second halves of the larval stage than they did during the egg stage or the post-capping period (Tabl. 4). Significant pollen use differences were not found for either 0 - or 100-cell colonies for the four periods analyzed.

\section{Brood Reared}

Mean percentages of larvae reared by colonies that were given 400 (69\% $\pm 3 \%)$ and $100(74 \% \pm 11 \%)$ cells of brood were not significantly different. Mortality was not attributed to insufficient pollen storage because pollen was available through the experiment.

\section{DISCUSSION}

The amount of pollen hoarded by a honey-bee colony is the net result of behaviors which lead to either the collection of pollen or the use of pollen. These behaviors are regulated by many factors, some of which are experimentally controlled more easily than others. In this experiment colony size, colony temperature, access to pollen, access to sugar syrup, age of bees, age of brood and levels of brood were controlled.

Amounts of pollen collected, stored and used by colonies increased with brood level. Pollen collection was greatest during the egg stage and decreased through the remaining days of the experiment. High levels of pollen collection early in the experiment might be attributed to small amounts of stored pollen. Even colonies with no brood collected and stored more pollen during the first few days of the experiment than later, seemingly as a response to empty comb. Empty comb has been found to stimulate nectar foraging (RINDERER and BAXTER, 1978). If such a stimulation occurrs for pollen foraging it would allow bees to collect pollen when pollen stores are low.

Colonies were stimulated to collect pollen by the presence of eggs and larvae, and stimulated to use pollen by the presence of larvae, particularly older larvae. Colony responses to the brood stimuli resulted in pollen storage that was sufficient for rearing the different amounts of brood that were given to the colonies.

Received for publication in August 1985. Accepted for publication in October 1985.

\section{ACKNOWLEDGEMENTS}

This investigation was supported in part by cooperative agreement 12-14-7001-1004 with the United States Department of Agricultural, by the Ohio Agricultural Research and Development 
Center, and by the Louisiana Agricultural Experiment Station. We thank Victor C. THOMPson for technical assistance and the Instruction and Research Computer Center at The Ohio State University for computer facilites. Part of the cost of publication was provided by the James I. Hambleton Apicultural Memorial Award Fund of 'The Ohio State University.

\title{
RÉSUME
}

\section{RELATIONS ENTRE DIVERSES QUANTITES DE COUVAIN ET LA RECOLTE ET L'UTILISATION DU POLLEN PAR L'ABEILLE}

Cette étude porte sur le rôle du pollen dans l'organisation de la colonie et en particulier dans la récolte $\mathrm{du}$ pollen, son utilisation et les soins au couvain et sur les relations entre ces facteurs lorsque varient les quantités de couvain. On a retenu 3 niveaux de couvain $(0,100$, et 400 cellules).

On a placé 3 ruches d'observation mono-cadres dans des cages de vol, sous un auvent (RothenbuHLer et al., 1968), et introduit dans chaque ruche environ 1000 ouvrières (âgées de 0-24 h) provenant de la même colonie. Lorsque les abeilles ont atteint l'âge de 10 à 12 jours, chaque colonie a été dressée sur du sirop de sucre (2,9 molar) dans une boîte de Pétri (WenNer, 1961) placée sur une table à $3 \mathrm{~m}$ de l'entrée de la ruche.

On a fait 3 essais qui ont commencé respectivement le 20 mai, le 13 juin et le 5 juillet, et ont duré 12 jours chacun. Chaque essai comprenait l'éclosion des æufts, l'operculation du couvain et une période de 2 jours suivant l'operculation.

Au cours de l'expérimentation, chaque matin entre $9 \mathrm{~h}$ et $10 \mathrm{~h}$, on disposait $20 \mathrm{ml}$ de sirop de sucre sur une table à l'intérieur de la cage de vol de chaque colonie. Deux heures plus tard, 2 boîtes de Pétri contenant au total $20 \mathrm{~g}$ de pollen broyé étaient placées sur la table. Au moment où l'on plaçait le pollen sur la table, le sirop de sucre était épuisé de sorte qu'on pouvait n'observer que l'activité de récolte du pollen. Les butineuses avaient accès au pollen pendant $5 \mathrm{~h}$.

La récolte de pollen a été mesurée selon 2 méthodes : 1) Poids de pollen : quantité de pollen prélevé au cours d'une période de butinage de 5 h. 2) Butineuses de pollen : nombre d'abeilles récoltant du pollen pendant 3 périodes de $5 \mathrm{mn}$ chacune. La quantité relative de pollen utilisée par chaque colonie sur une période de $16 \mathrm{~h}$ a été obtenue en soustrayant le nombre de cellules renfermant du pollen à $9 \mathrm{~h}$ du matin du nombre de cellules renfermant du pollen à la fín de la période de butinage du pollen du jour précédent.

Les quantités de pollen récoltées (Tabl. 2 et 3), stockées (Tabl. 1) et utilisées (Tabl. 4) par les colonies augmentent avec la quantité de couvain. La récolte de pollen est maximum pendant le stade cuf, puis décroît durant le reste de l'expérience. La présence d'oufs et de larve stimule les colonies à récolter le pollen, la présence de larves, particulièrement de larves âgées, stimule l'utilisation du pollen. Les réactions de la colonie aux stimuli du couvain se sont manifestées par le stockage du pollen en quantités suffisantes pour élever les diverses quantités de couvain fournies aux colonies.

\section{ZUSAMMENFASSUNG}

\author{
BEZIEHUNGEN ZWISCHEN UNTERSCHIEDEN IN DER BRUTMENGE \\ UND DEM SAMMELN UND DEM VERBRAUCH VON POLLEN \\ DURCH DIE HONIGBIENE (APIS MELLIFERA)
}

Diese Untersuchung befaßt sich mit der Rolle des Pollens in der Organisation des Volkes, und zwar besonders mit dem Pollensammeln, dem Pollenverbrauch und der Brutpflege, und die Beziehungen dieser Faktoren, wenn die Brutmengen geändert werden. Drei Stufen von Brutmengen wurden eingesetzt : 0,100 und 400 Zellen. 
Drei Einwaben-Beobachtungskästen waren unter einem Schutzdach mit angebauten Flugkäfigen (RotheNBUHLeR et al., 1968) aufgestellt. Ungefähr 1000 Arbeitsbienen im Alter von 0-24 St., alle aus demselben Volk stammend, wurden in jeden dieser Kästen gesetzt. Sobald die Bienen 10 bis 12 Tage alt waren, erfolgte eine Dressur des Volkes (WenNer, 1961) auf Zuckersyrup (2.9 molar) in einer Petrischale, die in $3 \mathrm{~m}$ Entfernung vom Flugloch auf einem Tisch aufgestellt war.

Drei Versuche mit Beginn am 20. Mai, 13. Juni und 5. Juli wurden durchgeführt. Jeder Versuch dauerte zwölf Tage und umfaßte das Ausschlüpfen der Eier, das Verdeckeln von Brut und eine Periode von zwei Tagen im Anschluß an das Deckeln der Brut.

An jedem Morgen der Versuchszeit wurden zwischen 9.00 und 10.00 Uhr $20 \mathrm{ml}$ Zuckersyrup für jedes Volk innerhalb des Flugkäfigs aufgestellt. Zwei Stunden später wurden zwei Petrischalen mit insgesamt $20 \mathrm{~g}$ gemahlenem Pollen auf dem Versuchstisch angeboten. $\mathrm{Zu}$ der Zeit, wenn der Pollen dargeboten wurde, war der Syrup schon abgenommen, so daß nur die Pollensammelaktivität zu beobachten war. Der Pollen war für die Sammlerinnen für fünf Stunden zugänglich.

Das Pollensammeln wurde täglich nach zwei verschiedenen Methoden gemessen : 1) Pollengewicht $=$ Menge des während der fünfstündigen Trachtperiode abgenommenen Pollens. 2) Pollensammler = Zahl der pollensammelnden Bienen, gezählt während drei Perioden zu je fünf Minuten. Die relative Pollenmenge, die von jedem Volk während einer 16-Stundenperiode verbraucht wurde, konnte auf die Weise geschätzt werden, daß man die Zahl der Pollenzellen um 9.00 Uhr am Morgen von der Zahl der Pollenzellen am Ende der Pollensammelperiode am vergangenen Tag abzog.

Die Pollenmenge, die gesammelt (Tab. 2 und 3), eingelagert (Tab. 1) und verbraucht wurde, stieg mit der Brutmenge. Pollensammeln war am stärksten während des Eistadiums und nahm im Laufe der restlichen Tage des Experiments ab. Die Völker wurden durch die Anwesenheit von Eiern und Larven zum Pollensammeln stimuliert, und sie wurden durch die Anwesenheit von Larven - besonders von solchen höheren Alters - zum Pollenverbrauch angeregt. Die Reaktion des Volkes auf den Brutreiz führte zu einer Polleneinlagerung, die ausreichte, um die unterschiedliche Brutmenge aufzuziehen, die den Völkern in Pflege gegeben worden war.

\section{REFERENCES}

FrLmer R.S., 1932. - Brood area and colony size as factors in activity of pollination units. J. Econ. Entomol., 25, 336-343.

FreE J.B., 1967. - Factors determining the collection of pollen by honeybee foragers. Anim. Behav., 15, 134-144.

Fuxuda H., 1960. - Some observations on the pollen foraging activities of the honey bee Apis mellifera L. (Preliminary report). J. Fac. Sci. Hokkaido Univ. Ser. VI. Zool., 14, 381-386.

JAYCOX E.B., 1970. - Honey bee foraging behavior : Responses to queens, larvae and extracts of larvae. Ann. Entomol. Soc. Am., 63, 1689-1694.

Louveaux J., 1950. - Observations sur le déterminisme de la récolte du pollen par les colonies d'abeilles. C.R. Acad. Sci., Paris, 231, 921-922.

Rinderer T.E., Baxter J.R., 1978. - Effect of empty comb on hoarding behavior and honey production of the honey bee. J. Econ. Entomol., 71, 757-759.

Rothenbuhler W.C., Thompson V.C., McDermott J.J., 1968. - Control of the environment of honeybee observation colonies by the use of hive-shelters and flight-cages. J. Apic. Res., 7, 151-155.

Todp F.E., ReEd C.B., 1970. - Brood measurement as a valid index to the value of honey bees as pollinators. J. Econ. Entomol., 63, 148-149.

Wenner A.M., 1961. - A method of training bees to visit a feeding station. Bee World, 42, 8-11. 